\title{
COMMUNITY STRUCTURE OF MIGRATORY WATERBIRDS AT TWO IMPORTANT WINTERING SITES IN A SUB-HIMALAYAN FOREST TRACT IN WEST BENGAL, INDIA
}

\author{
Asitava Chatterjee', Shuvadip Adhikari², Sudin Pal*2, \\ Subhra Kumar Mukhopadhyay ${ }^{2}$
}

\begin{abstract}
Chatterjee A., Adhikari S., Pal S. Mukhopadhyay S. K. 2020. Community structure of migratory waterbirds in two important wintering sites at sub-Himalayan forest tract in West Bengal, India. Ring 42: 15--37

The waterbird community structures of two sub-Himalayan wetlands (Nararthali and Rasomati) situated in forested areas were compared during the wintering period. These wetlands had similar geophysical features but were subject to different conservation efforts. Sixty species of waterbirds, including four globally threatened species, were recorded during the study. Nararthali was found to be more densely inhabited (116.05 \pm 22.69 ind./ha) by birds than Rasomati (76.55 \pm 26.47 ind./ha). Density increased by $44.6 \%$ at Nararthali and by $59 \%$ at Rasomati over the years of the study, from 2008 to 2015. Winter visitors increased considerably at Nararthali (66.2\%), while a $71.1 \%$ decrease at Rasomati clearly indicated degradation of habitat quality at that site during the later years. Luxuriant growth of Eichhornia crassipes, siltation, poor maintenance and unregulated tourist activities were the key factors leading to the rapid degradation of Rasomati. Nararthali, on the other hand, a well-managed wetland habitat, showed an increasing trend in bird densities. Therefore, poor habitat management and rapid habitat alterations were observed to be the main reasons for depletion of bird density in the wetlands of eastern sub-Himalayan forest regions.
\end{abstract}

${ }^{1}$ Office of the Divisional Forest Officer, Rupnarayan Division, Medinipur, West Bengal, India; ${ }^{2}$ Ecotoxicology Project Laboratory, Government College of Engineering and Leather Technology, Salt Lake, Kolkata, West Bengal, India. *Corresponding Author: Sudin Pal: sudindgp1@gmail.com

Keywords: Buxa Tiger Reserve, Patlakhawa Protected Forest, Dooars, Terai, vegetation cover, wetland management 


\section{INTRODUCTION}

Waterbirds are a diverse group of birds which are ecologically dependent on different types of wetlands. Waterbirds are facing a global threat of population decline (Wang et al. 2017, Haq et al. 2018). Global climate changes affect the migratory behaviour of waterbirds (Crick 2004, Miller-Rushing et al. 2008, Both et al. 2009), including decreasing migratory distances (Visser et al. 2009), changes in arrival time (Jonzén et al. 2006), and declining population size (Both et al. 2006). The wetlands of Asia are particularly affected by various human activities (Upadhyay and Saikia 2012, Ma et al. 2014). The complex dynamics of waterbird community structures are influenced by many natural and anthropogenic factors (Ward et al. 2010, Liordos et al. 2014). Long-term studies in wetlands provide useful information for assessment of their importance in terms of conservation (Paracuellos and Telleria 2004) and for ascertaining possible causes of the decline in waterbird populations (Paton et al. 2009, Mundava et al. 2012). The avian community of a given site is also used to formulate an index of biotic integrity, in order to evaluate a gradient of human disturbance from near-pristine to degraded habitat (O'Connell et al. 2000). India is a highly populated developing nation which is losing its wealth of wetland ecosystems due to anthropogenic pressures and consequent decimation of wetland- -dependent bird populations and other biota (Das 2012). While the large pristine lakes of the Trans-Himalayas and Shivalik Hills are spared, the pristine wetlands at the foothills of the Himalayas (known locally as the Terai and Dooars) are steadily encroached upon for various social development purposes. The wetlands of the Himalayan foothills have been chosen for ages by various species of migratory birds as suitable wintering and staging sites with ample foraging resources (Chatterjee et al. 2017). Altitudinal gradients, varied forest types, and habitat heterogeneity support diversified flora and fauna at the foothills of the Himalayas, including rich avifauna (Mohan and Kumar 2010, Acharya et al. 2011, Joshi et al. 2012, Naithani and Bhatt 2012, Chatterjee et al. 2020). Pandit et al. (2007) cautioned that large-scale deforestation in the Indian Himalaya would lead to the extinction of endemic taxa, including the Himalayan foothills. Rapid urbanization and growing tea estates have resulted in indiscriminate degradation and fragmentation of wildlife habitat in the past century, especially at the foothills of the Eastern Himalaya. In the last few decades, several wildlife sanctuaries, national parks, and tiger and elephant reserves have been designated to protect the rich biodiversity of the area. However, various anthropogenic pressures still persist and often lead to human-wildlife conflict. Regular flooding, the most common natural disturbance in the Himalayan foothills (the Terai and Dooars) is affecting not only the livelihood of human settlers at the forest-fringe, but also the biodiversity of the region (Das 2012). However, Gopi Sundar and Kittur (2013) reported that long-term intensive use of wetlands in agriculture has not affected the biodiversity of the wetland. Datta (2011) points out that the wetlands of the Eastern Himalayan foothills are used indiscriminately to tap resources and are of local socio-economic importance owing to agriculture, pisciculture and recreational practices. However, such anthropogenic in- 
terventions pay little attention to wetland-dependent biota. Sub-Himalayan wetlands are hotspots for waterbirds in the region, but they differ in terms of how they are managed, and therefore may have different carrying capacity for waterbirds. Our study areas are located in the Eastern Himalayan forested foothills in the northern part of West Bengal, a province of India. This region is at the junction of two hotspots, the Himalaya Biodiversity Hotspot and the Indo-Burma Biodiversity Hotspot, adjacent to the two important Endemic Bird Areas: the Eastern Himalayan and Assam Plains EBAs (Islam and Rahmani 2004). However, few published works have focused exclusively on the diversity and ecology of waterbirds from sub-Himalayan habitats (Datta 2011, 2014; Chatterjee et al. 2013, 2017). The present study was carried out in two wetland habitats in the Eastern Himalayan foothills, located in close proximity $(\sim 40 \mathrm{~km})$. One of these, the Nararthali wetland, was located within the Buxa Tiger Reserve and National Park (BTR), rich in biodiversity, and was under effective management strategies with serious conservation efforts. These included restricted entry by visitors, periodic cleaning of floating macrophytes, and undisturbed thickets of shore vegetation. BTR had been declared an Important Bird and Biodiversity Area (IN317) by BirdLife International in 2004 (BirdLife International 2016). The other study site, the Rasomati wetland, was located in the Patlakhawa Protected Forest (PPF), with minimum conservation efforts. Unregulated tourism is allowed at this site, and in winter people from South and North Bengal pour in for noisy picnics and day visits. Moreover, the floating weeds of this wetland, mainly a thick blanket of water hyacinth, are not regularly cleaned, and the peripheral areas are available for regular grazing by nearby villagers' domestic cattle. Surprisingly, no long-term study has been carried out on wintering waterbirds in the Himalayan foothills. This study was limited to only two wetlands in the Himalayan foothills, important staging and wintering sites for migratory waterbirds, in the context of management regimes. Despite this limitation, we believed that a comparison of inter-annual variations in waterbird numbers in even two wetlands would be important, given the paucity of information on wintering habitats of South Asia (Aarif et al. 2017). Two wetlands of comparable size and in a similar biotope, i.e. inside forests of the Eastern Himalayan foothills, were chosen to compare any reduction in abundance over a period of seven years and to record the impact of a stricter habitat management regime on avian diversity and density. The similar macro-climatic and geomorphological conditions but contrasting management regimes for these two wetlands provided the opportunity to investigate possible factors affecting the waterbird community structure with regard to conservation.

\section{MATERIALS AND METHODS}

\section{Study area}

The Himalayan foothills provide climatic and habitat conditions that attract avian visitors for wintering and staging (Chatterjee et al. 2020). The region is crossed by a number of rivers that originate in the Himalayas, and their depositions have formed the floodplain landmass over a long geological time. Over time, these rivers have 
changed their courses and formed oxbow lakes, a type of lentic freshwater wetland (wetland type code 1102, Indian Space Research Organization, 2011) with comparable geophysical features (Rudra 2012). The wetlands under study were such oxbow lakes, having undergone retrogressive changes over time to appear as today's shallow wetlands. Nararthali originated from the Rydak River and Rasomati from the Torsha River (Fig. 1).

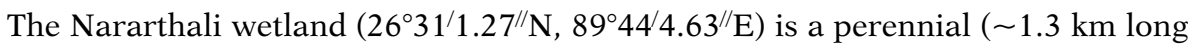
and $\sim 50 \mathrm{~m}$ wide, mean depth $2.75 \mathrm{~m}$ ) wetland ecosystem with an area of 6.5 ha at an altitude of $57 \mathrm{~m}$ msl, located under Buxa Tiger Reserve and National Park. Native common reed (Phragmites karka) in marshy areas, grassy meadows, sedges, and mudflats have supported a variety of birds.

The Rasomati wetland $\left(26^{\circ} 26^{\prime 4} 4.68^{/ / N}, 89^{\circ} 19^{\prime} 58.59^{/ /} \mathrm{E}\right)$ is located in the Patlakhawa Protected Forest under the Coochbehar Forest Division. This wetland is also a perennial ( $\sim 1 \mathrm{~km}$ long and $80 \mathrm{~m}$ wide, mean depth $2 \mathrm{~m}$ ) wetland ecosystem, identified as a designated wetland under the National Wetland Conservation Programme (NWCP) of MoEF, Government of India in 2009 (Conservation and Survey Division, MoEF, GoI 2009). The Rasomati wetland covers an area of approximately 8.0 ha, and seasonal fluctuation of the watershed area is a regular phenomenon. The area is relatively flat topographically, with a mean altitude of $52 \mathrm{~m}$ msl. This wetland is densely infested by water hyacinth for most of the year unless it is manually exterminated.

The extent of surface coverage of the wetland by floating vegetation (especially E. crassipes) was calculated by areal observation (from watchtowers) and plotting on graph paper throughout the study period. Each year was divided into pre-monsoon (March-April), monsoon (July-August), and post-monsoon (October-November) seasons to collect data on the vegetation cover of the surface water. The Eastern Himalayan foothills undergo peak monsoon in July and August. Due to increased allochthonous input of rain water, luxuriant growth of aquatic macrophytes is observed in the wetlands. Four observations of floating macrophytes each season, i.e. premonsoon, monsoon and post-monsoon, were averaged and presented in tabular form as percentage cover of floating vegetation in comparison to open water. The climate of the study area is classified as tropical monsoon, with heavy rainfall (annual average $3000-5000 \mathrm{~mm}$ ), and the temperatures are seldom excessive (ranges between $8^{\circ} \mathrm{C}$ and $38^{\circ} \mathrm{C}$ ).

\section{Waterbird data collection}

To estimate wetland bird richness and abundance we used the line transect method at random. We conducted three $1 \mathrm{~km}$ transect avian counts along the wetlands, recording birds out to $50 \mathrm{~m}$ from the transect line using a TruePlus 360 Laser range finder. All birds observed at distances of more than $50 \mathrm{~m}$ on both sides of the transect line were recorded, provided they were within $50 \mathrm{~m}$ perpendicular to the transect. We relied on raw avian count data as an index of abundance. Distant counts undoubtedly remain a standard method for sampling many migratory waterbird species because they are easy to implement. We conducted an avian count once in a month during wintering months (October through March) for seven successive sea- 

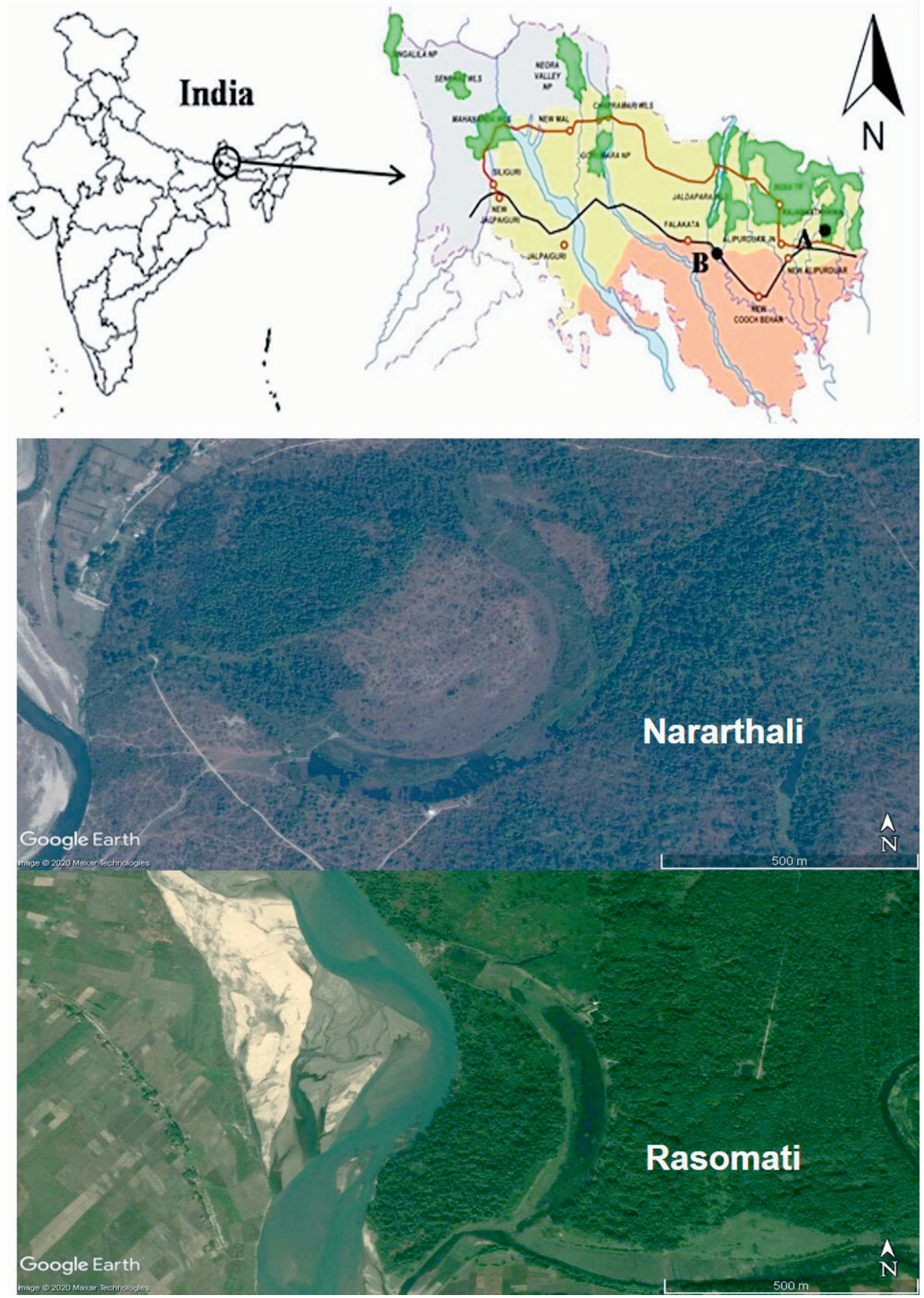

Fig. 1. Location of the study sites; A - Nararthali wetland and B - Rasomati wetland (India and West Bengal maps not to scale). Colour green in the top panel - protected areas. 
sons (2008/2009 through 2014/2015). Counts were conducted at three time intervals (6:00-7:00, 12:00-13:00 and 17:00-18:00) and averaged to obtain representative data (Gibbons and Gregory 2006). Three trained observers performed avian counts independently. Having more than one observer conducting avian counts independently at the same time and site had the additional advantage of minimizing errors in species identification, because each observer provided a check on the other's identification of species. Similarly, having three observers each estimating the distance to the birds would ensure the precision of these estimates. These measures were taken to enable robust inferences about avian counts, beyond mere presence/absence information. The counts were divided into three intervals of equal length. At each sampling time we traversed all the sides of the wetland where it was approachable. We also recorded the time and weather conditions at the start of each sampling. Birds flying or perching were also recorded separately along with those using the habitat directly. Avian counts made by three independent observers for three different time spans on each day and for three consecutive days constituted 27 samples for each month, which were averaged to obtain the representative data for the month. We also conducted random binocular-field counts of the populations of birds to obtain a more robust area-wise estimate (Bibby et al. 1992, Gopal 1995, Chatterjee et al. 2013, 2017) and species identification. We standardized area coverage of the binocular field by averaging three measurements of ground cover on an open field at six selected distance ranges: 10, 20, 30, 40, 50 and $100 \mathrm{~m}$. At 20 sampling points on the shoreline, at intervals of $100 \mathrm{~m}$, we recorded the total number and number of each species using binocular fields at each sampling spot, randomly chosen at five different sighting distances ranging from 10-100 m. Binocular-field counts included all avian species, either resting on the bank or reeds or wandering on the bank. We followed Grimmett et al. (2011) for bird identification and nomenclature. Bird species representing the families Accipitridae, Alcedinidae, and Motacillidae were designated as wetlanddependent and associated birds, and the rest were waterbirds (Kumar et al. 2005). We also considered grebes (family Podicipedidae) and ducks (family Anatidae) as a separate group. Waders were also considered as a distinct avian group represented by the families Ciconiidae, Ardeidae, Charadriidae, Scolopacidae, and Jacanidae as per the works of Ali and Ripley (1987) and Kumar et al. (2005).

\section{Weather data collection}

Meteorological data, i.e. mean maximum and minimum temperatures, differences between maximum and minimum temperatures, rainfall, and day length (Table 1 and 2) were obtained from available data sources of the Meteorological Department, Govt. of India.

\section{Data analyses}

Raw data $(n=42)$ were analysed in two different temporal (yearly and monthly) scales to compare and comment on the avian community patterns of the Nararthali and Rasomati wetlands, separated by nearly $40 \mathrm{~km}$, within eastern sub-Himalayan forest tracts. 
Table 1

Present climatic conditions of study sites ( $\mathrm{SR}=$ incident solar energy: Max. AT = maximum air temperature; Min. AT = minimum air temperature; $\mathrm{TD}=$ difference between maximum and minimum air temperature; DL = day length)

\begin{tabular}{|l|c|c|c|c|c|c|}
\hline & October & November & December & January & February & March \\
\hline $\begin{array}{l}\text { SR } \\
(\text { Kcal m }\end{array}$ & $0.8 \pm 0.1$ & $1.2 \pm 1.2$ & $2.2 \pm 0.2$ & $1.9 \pm 0.7$ & $2.2 \pm 0.2$ & $2.2 \pm 0.5$ \\
\hline Max. AT $\left({ }^{\circ} \mathrm{C}\right)$ & $31.6 \pm 0.9$ & $29.0 \pm 0.7$ & $25.4 \pm 0.9$ & $23.6 \pm 1.1$ & $27.0 \pm 1.6$ & $31.0 \pm 1.0$ \\
\hline Min. AT $\left({ }^{\circ} \mathrm{C}\right)$ & $21.4 \pm 0.9$ & $15.0 \pm 1.6$ & $11.8 \pm 1.5$ & $9.8 \pm 0.8$ & $11.2 \pm 0.8$ & $16.2 \pm 0.8$ \\
\hline TD $\left({ }^{\circ} \mathrm{C}\right)$ & $10.2 \pm 0.8$ & $14.0 \pm 1.6$ & $13.6 \pm 1.5$ & $13.8 \pm 0.5$ & $15.8 \pm 0.8$ & $14.8 \pm 1.1$ \\
\hline Rainfall $(\mathrm{mm})$ & $196 \pm 155.7$ & $4.8 \pm 7.8$ & $2.0 \pm 4.5$ & $18.2 \pm 24.6$ & $17.4 \pm 19.8$ & $36.0 \pm 41.9$ \\
\hline DL (hr:min:s) & $11: 31: 54$ & $10: 51: 52$ & $10: 31: 24$ & $10: 42: 02$ & $11: 16: 06$ & $12: 17: 00$ \\
& $\pm 0: 13: 15$ & $\pm 0: 09: 30$ & $\pm 0: 02: 11$ & $\pm 0: 07: 41$ & $\pm 0: 11: 25$ & $\pm 0: 14: 00$ \\
\hline
\end{tabular}

Table 2

Comparison of mean air temperature (AT) and rainfall recorded between 1901-2000 and 2008-2015

\begin{tabular}{|l|c|c|c|c|c|c|}
\hline \multirow{2}{*}{} & \multicolumn{2}{|c|}{ Previous record $(1901-2000 *$} & \multicolumn{3}{c|}{ Present status (2008-2015) } \\
\cline { 2 - 7 } & $\begin{array}{c}\text { Max. AT } \\
\left({ }^{\circ} \mathrm{C}\right)\end{array}$ & $\begin{array}{c}\text { Min. AT } \\
\left({ }^{\circ} \mathrm{C}\right)\end{array}$ & $\begin{array}{c}\text { Rainfall } \\
(\mathrm{mm})\end{array}$ & $\begin{array}{c}\text { Max. AT } \\
\left({ }^{\circ} \mathrm{C}\right)\end{array}$ & $\begin{array}{c}\text { Min. AT } \\
\left({ }^{\circ} \mathrm{C}\right)\end{array}$ & $\begin{array}{c}\text { Rainfall } \\
(\mathrm{mm})\end{array}$ \\
\hline January & 23.7 & 9.6 & 8.3 & 23.6 & 9.8 & 18.2 \\
\hline February & 25.8 & 11.6 & 13.1 & 27.0 & 11.2 & 17.4 \\
\hline March & 29.9 & 15.8 & 40.7 & 31.0 & 16.2 & 36.0 \\
\hline April & 31.7 & 20.1 & 127.9 & 31.2 & 21.0 & 150.6 \\
\hline May & 31.0 & 22.2 & 377.6 & 32.0 & 23.0 & 310.4 \\
\hline June & 31.1 & 24.1 & 766.8 & 32.0 & 24.8 & 623.0 \\
\hline July & 31.3 & 24.9 & 813.4 & 32.0 & 26.2 & 684.8 \\
\hline August & 31.6 & 25.1 & 620.5 & 32.2 & 25.8 & 516.8 \\
\hline September & 31.3 & 24.3 & 519.0 & 32.8 & 25.0 & 417.0 \\
\hline October & 30.5 & 21.2 & 179.8 & 31.6 & 21.4 & 196.0 \\
\hline November & 28.1 & 15.4 & 9.7 & 29.0 & 15.0 & 4.8 \\
\hline December & 25.2 & 11.2 & 4.0 & 25.4 & 11.8 & 2.0 \\
\hline Mean values & $29.3 \pm 2.8$ & $18.8 \pm 5.8$ & $290.1 \pm 314.4$ & $29.9 \pm 3.0$ & $19.3 \pm 6.1$ & $248.1 \pm 255.6$ \\
\hline
\end{tabular}

To compare the inter-annual and inter-wetland variations in waterbird numbers, if any, over a span of seven consecutive years, we tested the data set for three statistical analyses. One-way analysis of variance (ANOVA) was computed to comment on the extent of differences in year-wise avian densities between study sites. Spatially constrained rarefaction (SCR) was used to estimate species richness that was directly comparable for areas that differed in spatial extent. Individual-based rarefaction and sample-based rarefaction were also applied to comment on the diversity, especially the species richness, of the study sites. SHE analysis was carried out to examine the relationship between $S$ (species richness), $H$ (Shannon diversity), and $E$ (evenness or dominance) in the samples, in order to compare the long-term trend in taxa biodiversity. The advantage of the SHE analysis was that it allowed for the separation of di- 
versity into two components, species richness $(S)$ and evenness $(E)$, within the same system and at the same time, so their mutual relationships could be described to explain the changes in biodiversity represented by the $H$ index (Morabito 2016). We used PAST 3.07, SPSS (version 16.0) and Statistica (version 8) for the statistical computations.

\section{RESULTS}

\section{Weather conditions at the study site}

The weather conditions at the study sites are shown in Tables 1 and 2. Mean maximum and minimum air temperatures and average rainfall values were compared between the last century (1901-2000) and the study period (2008-2015). Both the maximum and minimum monthly average air temperature values have slightly increased in recent times at the study locations, except for a few months. Overall mean annual maximum and minimum air temperatures have increased by $0.72^{\circ} \mathrm{C}$ and $0.48^{\circ} \mathrm{C}$, respectively. Mean rainfall has decreased in recent times, but the monthly mean values showed that rainfall during the winter months (October through March) increased marginally $(3.13 \mathrm{~mm})$.

\section{Avian assemblages}

Sixty species of waterbirds and wetland-dependent or associated birds from the Nararthali and Rasomati wetlands were recorded, including 30 winter visitors. A total of 51 species belonging to 12 families were recorded from the Nararthali wetland and 49 species belonging to 13 families from the Rasomati wetland (Table 3). There were 25 and 22 species of winter visitors recorded from the Nararthali and Rasomati wetlands, respectively. There were 40 species recorded from both of the wetlands, 11 were found exclusively at Nararthali, and nine only at Rasomati. The family Recurvirostridae (Pied Avocet, Recurvirostra avosetta) was exclusively recorded from the Rasomati wetland area.

The avian density pattern throughout the study period is shown in Fig. 2. In Nararthali, the yearly density fluctuated throughout the seven-year study. In the later years (2013/2014 and 2014/2015) avian density increased compared to previous years. The Rasomati wetland experienced a different pattern compared to that of Nararthali, with density generally decreasing in the later years (see Fig. 2). In Rasomati, the density grew during the winter seasons of 2008/2009, 2009/2010, and 2010/2011 and then began to fall clearly and continuously, reaching the lowest density in 2014/2015.

The Nararthali wetland experienced the highest bird density in 2013/14 (136.08 ind./ha) and the lowest in 2008/09 (91.91 ind./ha), whereas the density in the Rasomati wetland was highest in 2010/2011 (108.22 ind./ha) and lowest in 2014/2015 (34.00 ind./ha). In both the Nararthali and Rasomati wetlands, the maximum bird concentration was recorded in January (139.31 and 91.69 ind./ha respectively) and the lowest in October (88.31 and 60.33 ind./ha respectively). 


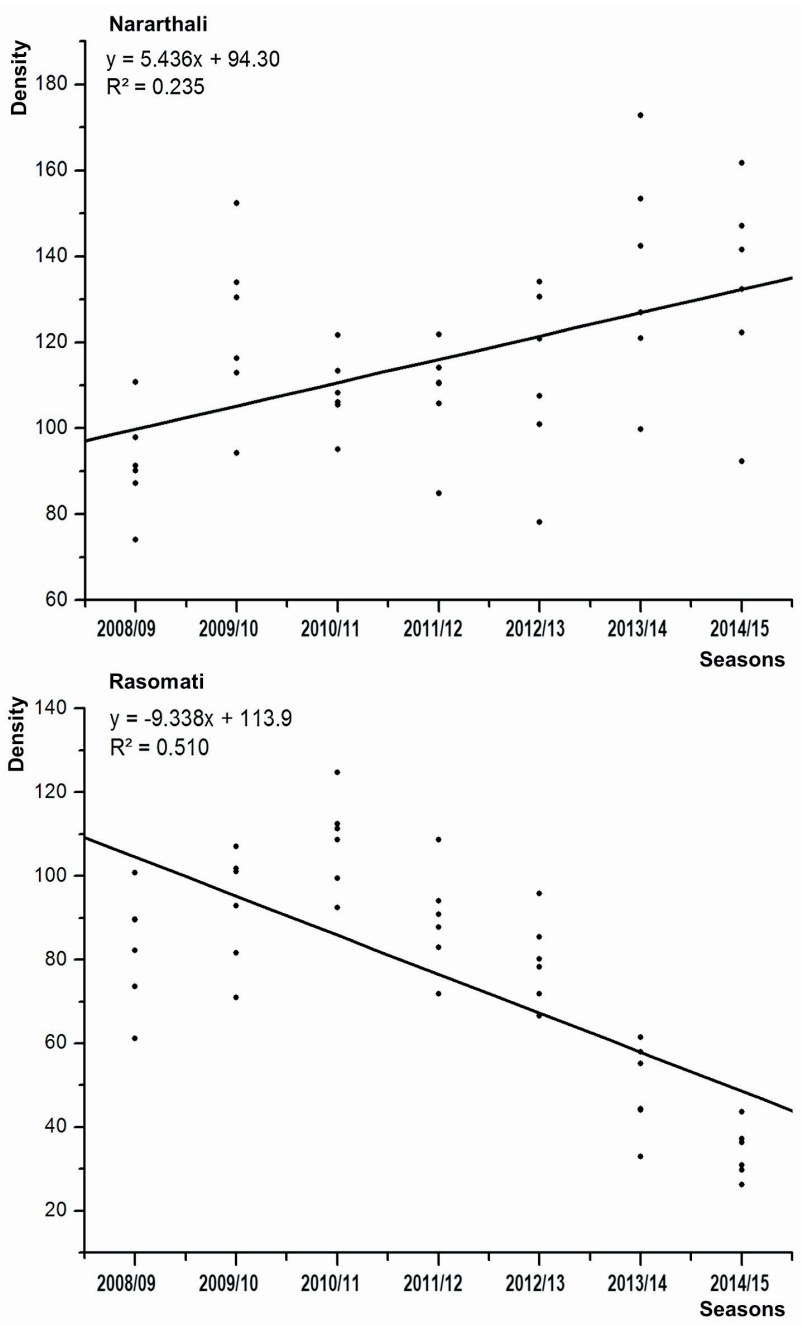

Fig. 2. Temporal changes in avian densities (individuals/ha) in seasons 2008/2009 to 2014/2015 at the Nararthali and Rasomati wetlands. Dotted lines indicate the upper and lower limits of the $95 \%$ confidence interval

In the Nararthali wetland, the Common Moorhen was dominant during the study (mean density $28.74 \pm 5.75$ ind./ha), closely followed by the Lesser Whistling-duck (mean density 28.66 \pm 6.62 ind./ha; Table 3). In contrast, the Lesser Whistling-duck was dominant in the Rasomati wetland (30.63 \pm 11.19 ind./ha), and its density was much higher than that of the next species, the Cattle Egret $(8.81 \pm 3.60$ ind./ha). Among the 51 species recorded in the Nararthali wetland, only 17 species contributed more than $1 \%$ of the mean avian assemblage. These 17 species included two wetland-associated bird species, seven ducks, one grebe, and seven waders. In the Rasomati wetland, 18 species, including four ducks, one grebe, and eight waders contributed more than $1 \%$ of the total mean bird density. According to the IUCN Red List (2016), 
four species recorded during the present study are globally threatened (one critically endangered and three vulnerable), while five were near-threatened species.

Table 3

Bird densities (mean \pm SD ind. ha ${ }^{-1}$ ) recorded from the Nararthali and Rasomati wetlands during wintering months of seven study seasons (2008/09 to 2014/15)

(CR - Critically Endangered, VU - Vulnerable, NT - Near Threatened, LC - Least Concern, R - Resident and WV - Winter visitor)

\begin{tabular}{|c|c|c|c|c|c|}
\hline Common name & Scientific name & $\begin{array}{l}\text { IUCN } \\
\text { status }\end{array}$ & $\begin{array}{c}\text { Migratory } \\
\text { status }\end{array}$ & $\begin{array}{c}\text { Nararthali } \\
\text { wetland }\end{array}$ & $\begin{array}{c}\text { Rasomati } \\
\text { wetland }\end{array}$ \\
\hline \multicolumn{6}{|c|}{ Anatidae } \\
\hline Lesser Whistling-duck & Dendrocygna javanica & LC & $\mathrm{R}$ & $28.66 \pm 6.22$ & $30.63 \pm 11.19$ \\
\hline Greylag Goose & Anser anser & LC & WV & $0.01 \pm 0.04$ & - \\
\hline Cotton Pygmy-goose & $\begin{array}{l}\text { Nettapus coromande- } \\
\text { lianus }\end{array}$ & $\mathrm{LC}$ & $\mathrm{R}$ & $1.32 \pm 0.79$ & $0.79 \pm 0.57$ \\
\hline Gadwall & Mareca strepera & LC & $\mathrm{WV}$ & - & $0.92 \pm 0.56$ \\
\hline Falcated Duck & Mareca falcata & NT & WV & $0.04 \pm 0.10$ & - \\
\hline Eurasian Wigeon & Mareca penelope & LC & WV & - & $0.07 \pm 0.19$ \\
\hline Mallard & Anas platyrhynchos & $\mathrm{LC}$ & WV & $0.25 \pm 0.36$ & $0.37 \pm 0.28$ \\
\hline Indian Spot-billed Duck & Anas poecilorhyncha & LC & $\mathrm{R}$ & $5.32 \pm 3.43$ & - \\
\hline Northern Shoveler & Spatula clypeata & $\mathrm{LC}$ & WV & - & $0.16 \pm 0.30$ \\
\hline Northern Pintail & Anas acuta & LC & WV & $1.25 \pm 0.32$ & - \\
\hline Common Teal & Anas crecca & LC & WV & $7.08 \pm 5.10$ & $2.86 \pm 1.39$ \\
\hline Red-crested Pochard & Netta rufina & LC & WV & $0.61 \pm 0.48$ & - \\
\hline Common Pochard & Aythya ferina & VU & WV & $0.69 \pm 0.43$ & $0.02 \pm 0.05$ \\
\hline Baer's Pochard & Aythya baeri & $\mathrm{CR}$ & $\mathrm{WV}$ & $0.03 \pm 0.08$ & - \\
\hline Ferruginous Duck & Aythya nyroca & NT & WV & $6.69 \pm 2.83$ & $0.64 \pm 0.19$ \\
\hline \multicolumn{6}{|c|}{ Podicipedidae } \\
\hline Little Grebe & Tachybaptus ruficollis & LC & $\mathrm{R}$ & $2.22 \pm 0.70$ & $1.31 \pm 0.32$ \\
\hline \multicolumn{6}{|c|}{ Ciconiidae } \\
\hline Asian Openbill & Anastomus oscitans & $\mathrm{LC}$ & $\mathrm{R}$ & $0.81 \pm 0.40$ & $1.81 \pm 0.45$ \\
\hline Lesser Adjutant & Leptoptilos javanicus & $\mathrm{VU}$ & $\mathrm{R}$ & $0.38 \pm 0.05$ & $0.30 \pm 0.09$ \\
\hline \multicolumn{6}{|c|}{ Ardeidae } \\
\hline Indian Pond Heron & Ardeola grayii & LC & $\mathrm{R}$ & $3.40 \pm 1.27$ & $5.07 \pm 3.98$ \\
\hline Purple Heron & Ardea purpurea & LC & $\mathrm{R}$ & - & $0.02 \pm 0.03$ \\
\hline Cattle Egret & Bubulcus ibis & LC & $\mathrm{R}$ & $4.05 \pm 1.55$ & $8.81 \pm 3.60$ \\
\hline Intermediate Egret & Ardea intermedia & LC & $\mathrm{R}$ & $0.33 \pm 0.15$ & $0.21 \pm 0.15$ \\
\hline Little Egret & Egretta garzetta & LC & $\mathrm{R}$ & $1.67 \pm 0.59$ & $1.65 \pm 1.09$ \\
\hline \multicolumn{6}{|c|}{ Phalacrocoracidae } \\
\hline Little Cormorant & Microcarbo niger & LC & $\mathrm{R}$ & $2.70 \pm 0.42$ & $2.04 \pm 0.70$ \\
\hline Indian Cormorant & $\begin{array}{l}\text { Phalacrocorax } \\
\text { fuscicollis }\end{array}$ & $\mathrm{LC}$ & $\mathrm{R}$ & $0.10 \pm 0.09$ & $1.76 \pm 0.60$ \\
\hline Great Cormorant & Phalacrocorax carbo & $\mathrm{LC}$ & WV & $0.04 \pm 0.07$ & - \\
\hline \multicolumn{6}{|c|}{ Accipitridae } \\
\hline Brahminy Kite & Haliastur indus & LC & $\mathrm{R}$ & - & $0.02 \pm 0.03$ \\
\hline Osprey & Pandion haliaetus & LC & $\mathrm{WV}$ & $0.13 \pm 0.07$ & $0.14 \pm 0.09$ \\
\hline
\end{tabular}




\begin{tabular}{|c|c|c|c|c|c|}
\hline Common name & Scientific name & $\begin{array}{l}\text { IUCN } \\
\text { status }\end{array}$ & $\begin{array}{c}\text { Migratory } \\
\text { status }\end{array}$ & $\begin{array}{c}\text { Nararthali } \\
\text { wetland }\end{array}$ & $\begin{array}{c}\text { Rasomati } \\
\text { wetland }\end{array}$ \\
\hline Grey-headed Fish Eagle & $\begin{array}{l}\text { Icthyophaga } \\
\text { ichthyaetus }\end{array}$ & NT & $\mathrm{R}$ & $0.07 \pm 0.06$ & $0.06 \pm 0.05$ \\
\hline $\begin{array}{l}\text { Eurasian Marsh } \\
\text { Harrier }\end{array}$ & Circus aeruginosus & LC & WV & $0.01 \pm 0.02$ & - \\
\hline Greater Spotted Eagle & Clanga clanga & $\mathrm{VU}$ & WV & $0.02 \pm 0.03$ & $0.02 \pm 0.03$ \\
\hline \multicolumn{6}{|c|}{ Rallidae } \\
\hline $\begin{array}{l}\text { White-breasted } \\
\text { Waterhen }\end{array}$ & $\begin{array}{l}\text { Amaurornis } \\
\text { phoenicurus }\end{array}$ & LC & $\mathrm{R}$ & $0.86 \pm 0.44$ & $1.28 \pm 0.52$ \\
\hline Watercock & Gallicrex cinerea & LC & $\mathrm{R}$ & $0.43 \pm 0.26$ & $0.21 \pm 0.26$ \\
\hline Purple Swamphen & Porphyrio porphyrio & LC & $\mathrm{R}$ & $0.58 \pm 0.38$ & $0.62 \pm 0.29$ \\
\hline Common Moorhen & Gallinula chloropus & LC & $\mathrm{R}$ & $28.74 \pm 5.75$ & $3.33 \pm 1.67$ \\
\hline Eurasian Coot & Fulica atra & LC & $\mathrm{R}$ & $0.98 \pm 0.70$ & $0.22 \pm 0.31$ \\
\hline \multicolumn{6}{|c|}{ Charadriidae } \\
\hline Northern Lapwing & Vanellus vanellus & NT & WV & $0.27 \pm 0.16$ & $0.57 \pm 0.40$ \\
\hline River Lapwing & Vanellus duvaucelii & NT & $\mathrm{R}$ & - & $0.28 \pm 0.27$ \\
\hline Grey-headed Lapwing & Vanellus cinereus & $\mathrm{LC}$ & WV & $1.40 \pm 0.92$ & $2.05 \pm 1.41$ \\
\hline Red-wattled Lapwing & Vanellus indicus & LC & $\mathrm{R}$ & $1.38 \pm 0.35$ & - \\
\hline Little Ringed Plover & Charadrius dubius & LC & $\mathrm{R}$ & $0.46 \pm 0.34$ & $0.60 \pm 0.25$ \\
\hline Kentish Plover & \begin{tabular}{|l} 
Charadrius \\
alexandrinus
\end{tabular} & LC & WV & - & $0.03 \pm 0.06$ \\
\hline \multicolumn{6}{|c|}{ Recurvirostridae } \\
\hline Pied Avocet & Recurvirostra avosetta & LC & WV & - & $0.01 \pm 0.02$ \\
\hline \multicolumn{6}{|c|}{ Scolopacidae } \\
\hline Common Snipe & Gallinago gallinago & LC & WV & $0.05 \pm 0.09$ & $0.17 \pm 0.18$ \\
\hline Marsh Sandpiper & Tringa stagnatilis & LC & WV & $0.08 \pm 0.09$ & $0.04 \pm 0.07$ \\
\hline Common Greenshank & Tringa nebularia & $\mathrm{LC}$ & WV & - & $0.04 \pm 0.08$ \\
\hline Wood Sandpiper & Tringa glareola & LC & WV & $0.04 \pm 0.05$ & $0.01 \pm 0.02$ \\
\hline Terek Sandpiper & Xenus cinereus & $\mathrm{LC}$ & WV & $0.03 \pm 0.05$ & - \\
\hline \multicolumn{6}{|c|}{ Common Sandpiper } \\
\hline Pheasant-tailed Jacana & $\begin{array}{l}\text { Hydrophasianus } \\
\text { chirurgus }\end{array}$ & LC & $\mathrm{R}$ & $1.61 \pm 1.46$ & $1.27 \pm 0.47$ \\
\hline Bronze-winged Jacana & Metopidius indicus & $\mathrm{LC}$ & $\mathrm{R}$ & $1.86 \pm 0.82$ & $1.77 \pm 0.64$ \\
\hline \multicolumn{6}{|c|}{ Alcedinidae } \\
\hline Stork-billed Kingfisher & Pelargopsis capensis & $\mathrm{LC}$ & $\mathrm{R}$ & $0.15 \pm 0.06$ & $0.44 \pm 0.23$ \\
\hline $\begin{array}{l}\text { White-throated } \\
\text { Kingfisher }\end{array}$ & Halcyon smyrnensis & LC & $\mathrm{R}$ & $0.94 \pm 0.23$ & $0.65 \pm 0.14$ \\
\hline Common Kingfisher & Alcedo atthis & $\mathrm{LC}$ & $\mathrm{R}$ & $0.52 \pm 0.13$ & $0.78 \pm 0.38$ \\
\hline Pied Kingfisher & Ceryle rudis & LC & $\mathrm{R}$ & - & $0.09 \pm 0.07$ \\
\hline \multicolumn{6}{|c|}{ Motacillidae } \\
\hline Yellow Wagtail & Motacilla flava & LC & WV & $0.17 \pm 0.10$ & $0.18 \pm 0.13$ \\
\hline Citrine Wagtail & Motacilla citreola & LC & WV & $0.23 \pm 0.17$ & $0.64 \pm 0.35$ \\
\hline Grey Wagtail & Motacilla cinerea & LC & WV & $0.12 \pm 0.10$ & $0.06 \pm 0.09$ \\
\hline White Wagtail & Motacilla alba & $\mathrm{LC}$ & WV & $0.18 \pm 0.15$ & $0.65 \pm 0.47$ \\
\hline White-browed Wagtail & $\begin{array}{l}\text { Motacilla madaraspa- } \\
\text { tensis }\end{array}$ & LC & $\mathrm{R}$ & $0.17 \pm 0.14$ & - \\
\hline
\end{tabular}




\section{Community structure}

SHE analysis represented evenness of samples in terms of expected and observed species richness of avian species in both the Nararthali and Rasomati wetlands. The results of the SHE analyses for both wetlands are presented in Fig. 3, and the values did not fluctuate significantly over the months of the study between study sites. Individual-based rarefaction values were much higher in the Nararthali wetland than in the Rasomati wetland (Fig. 4). During the seven years of the study in the Nararthali wetland, the rarefaction value was highest in 2013/2014, when the mean bird density was highest. The lowest rarefaction value in the Rasomati wetland was recorded during the 2014/2015 season. Sample-based rarefaction curves are presented in Fig. 5. The rarefaction values were higher for the Nararthali wetland than for the Rasomati wetland.
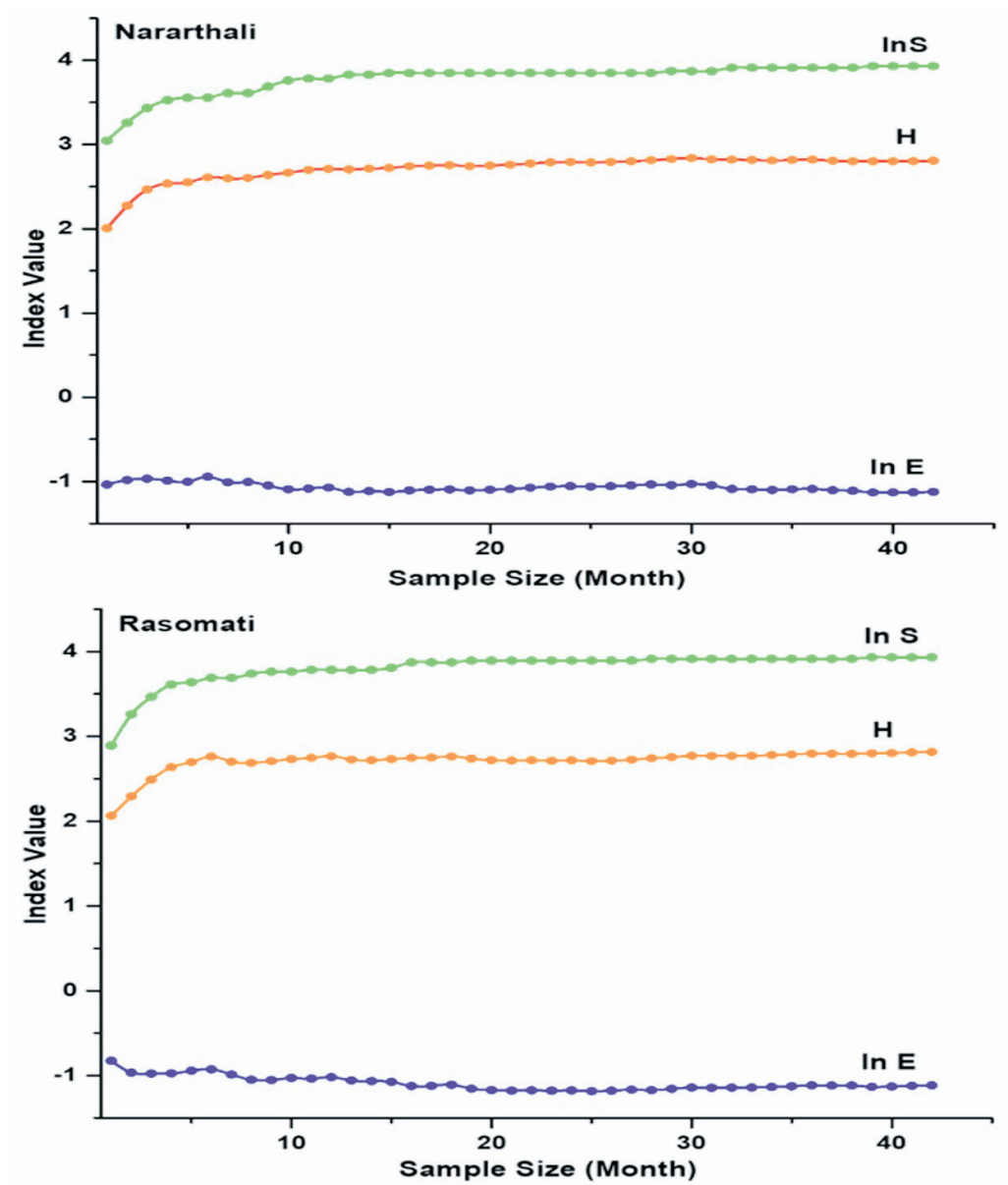

Fig. 3. Representation of SHE analysis of avian species recorded at the Nararthali and Rasomati wetlands 

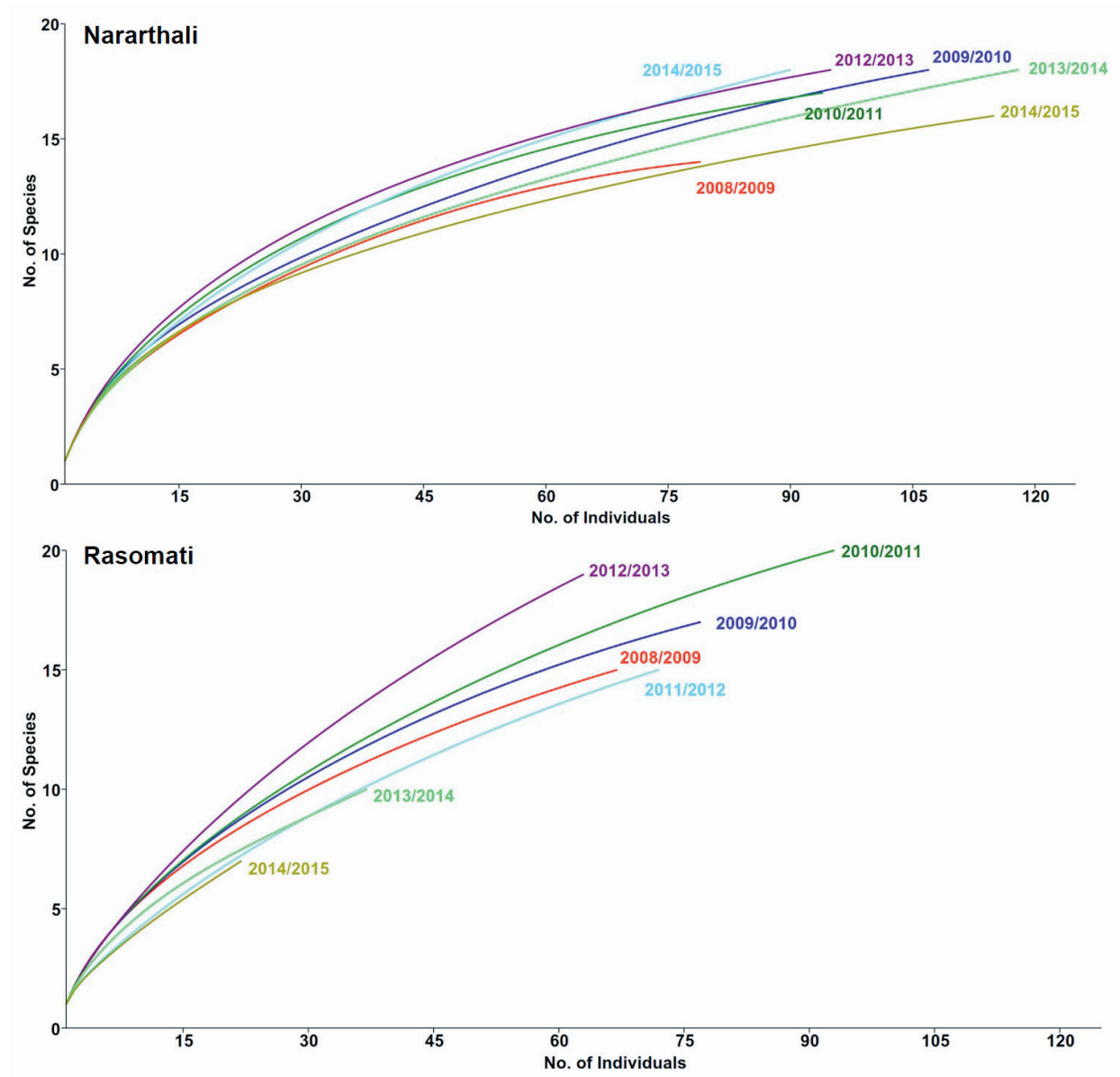

Fig. 4. Individual-based rarefaction curves for the Nararthali and Rasomati wetlands calculated for the years of the study

\section{Floating vegetation cover}

Eichhornia crassipes (Water hyacinth) was the most abundant and invasive floating macrophyte species found in both wetlands. Other free floating vegetation included Azolla pinnata (water velvet), Pistia stratiotes (water lettuce), and Salvinia sp. Generally, monsoon wetlands became more infested by macrophytes, which were subsequently cleared by the management (forest) authority prior to the arrival of winter visitors (Table 4). However, in 2012/2013 67\% of the Rasomati wetland was covered with floating vegetation. Also, in the monsoon of 2012 this wetland faced massive flooding that caused siltation. Therefore, from 2013 onwards a substantial portion of the wetland dried out (except during monsoon), with no surface water, and a large area has gradually been reclaimed as grassy meadow in more recent years. 


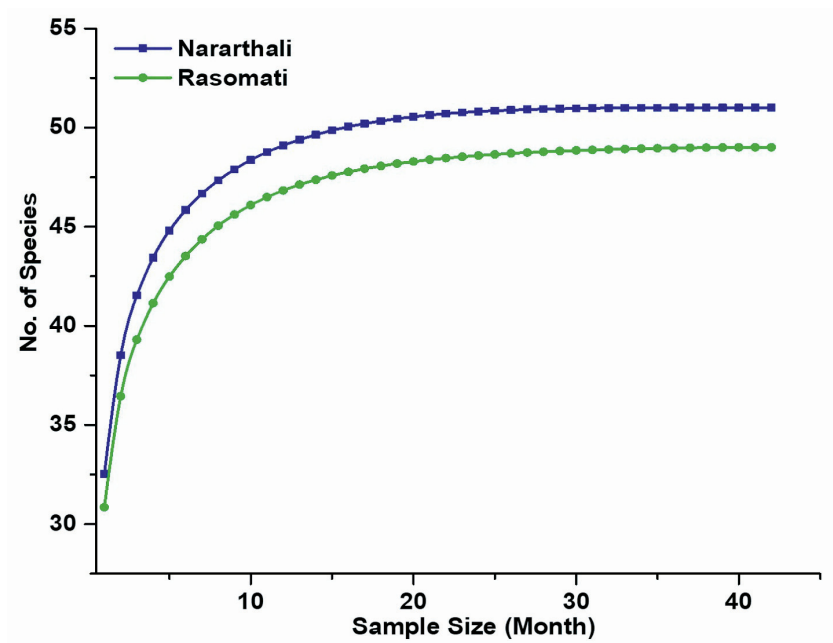

Fig. 5. Sample-based rarefaction curves for the Nararthali and Rasomati wetlands based on the months of the study

Table 4

Floating vegetation (especially water hyacinth, Eichhornia crassipes) cover (\%),

Post-monsoon: October-November, Pre-monsoon: March-April, Monsoon:

July-August (*Substantial portion dried out and reclaimed as grassy meadow)

\begin{tabular}{|c|c|c|c|}
\hline \multirow{2}{*}{} & Post-monsoon & Pre-monsoon & Monsoon \\
\cline { 2 - 4 } & \multicolumn{3}{|c|}{ Nararthali wetland } \\
\hline $2008 / 09$ & 25 & 35 & 75 \\
\hline $2009 / 10$ & 32 & 41 & 71 \\
\hline $2010 / 11$ & 29 & 42 & 75 \\
\hline $2011 / 12$ & 31 & 33 & 67 \\
\hline $2012 / 13$ & 35 & 37 & 67 \\
\hline $2013 / 14$ & 28 & 30 & 71 \\
\hline $2014 / 15$ & 38 & 35 & 76 \\
\hline & & Rasomati wetland & 80 \\
\hline $2008 / 09$ & 25 & 55 & 83 \\
\hline $2009 / 10$ & 29 & 52 & 88 \\
\hline $2010 / 11$ & 36 & 56 & 88 \\
\hline $2011 / 12$ & 41 & 58 & 43 \\
\hline $2012 / 13$ & 67 & 67 & 38 \\
\hline $2013 / 14 *$ & 12 & 13 & 15 \\
\hline $2014 / 15$ & 12 & \multicolumn{2}{|c|}{} \\
\hline
\end{tabular}

\section{Spatio-temporal comparison}

Year-wise comparison of mean avian density showed greater differences between the two wetlands in more recent years (Fig. 2). In 2010/2011 the mean avian density was quite similar in both wetlands, while after this year it decreased progressively in the Rasomati wetland during the wintering period. The results of ANOVA showed sig- 
nificant variation between the study sites for the years 2009/2010, 2011/2012, $2012 / 2013,2013 / 2014$, and 2014/2015. From 2011/2012 to 2014/2015, analysis of variance (ANOVA) showed significant differences in wintering waterbird density between the Rasomati and Nararthali wetlands, with $p$ values varying between 0.00002 and 0.026582 , while $F$ values varied between 6.750 and 95.803 . Year-wise changes in waterbird density showed a decreasing pattern (see Fig. 2) in recent years in the Rasomati wetland. In contrast, comparison of bird densities over the study period in the Nararthali wetland revealed a significant increase in density.

Densities of all waterbirds (grebes, ducks and waders) showed a fluctuation pattern that steadily decreased in later years at the Rasomati wetland (Fig. 6). Densities of different bird groups (duck and grebe density, wader density, and even resident bird density) also showed similar fluctuation patterns and decreased over recent years at the Rasomati wetland (Fig. 7). However, waders preferred to occupy the Rasomati wetland, and comparably higher densities were recorded from 2008/2009 to 2010/2011 than in more recent years. Even waders at Rasomati were recorded in
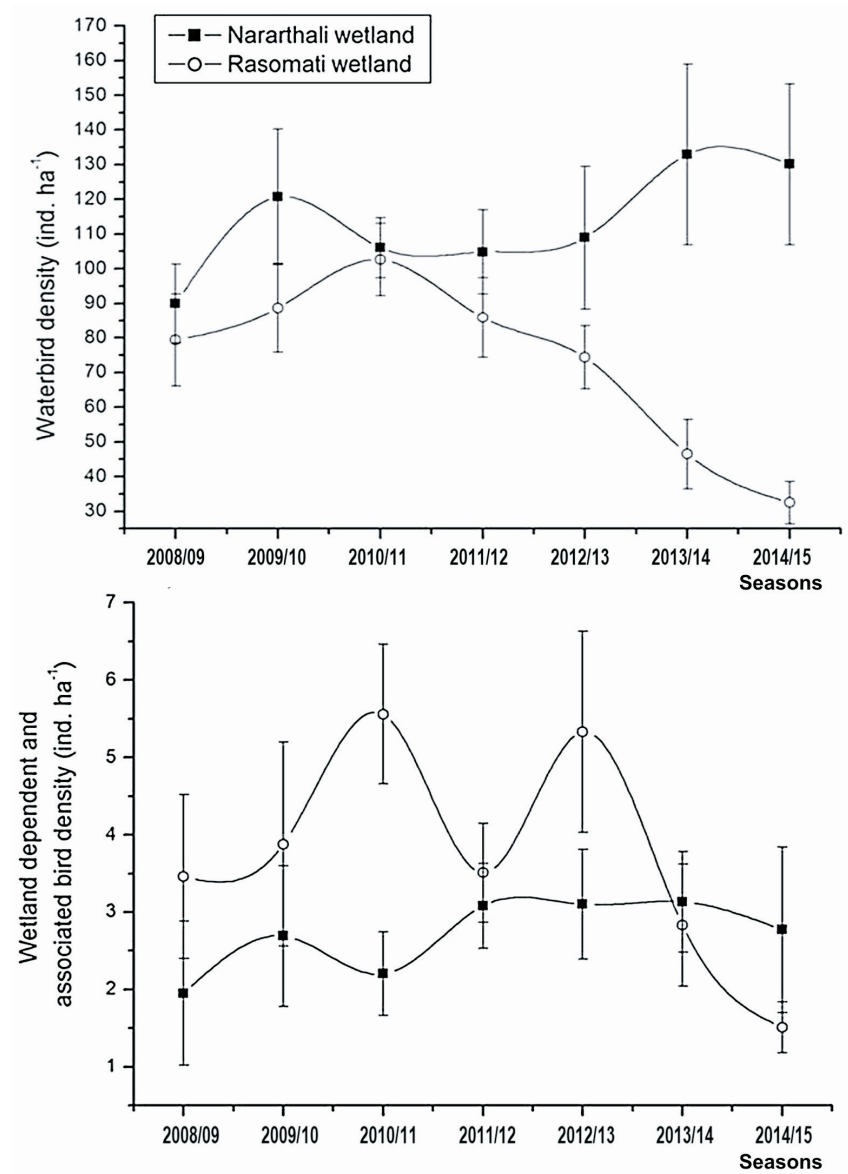

Fig. 6. Temporal changes in avian densities (mean \pm SD) at the Nararthali and Rasomati wetlands. All waterbirds and wetland-dependent and associated birds. 

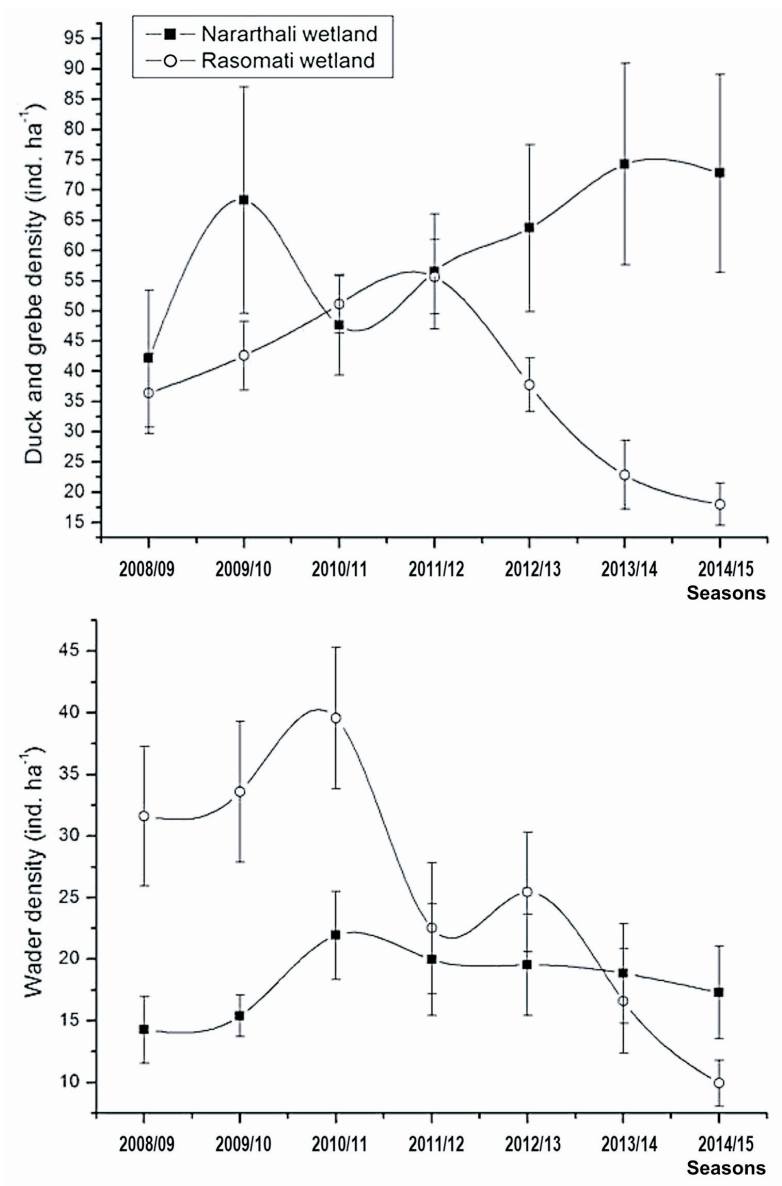

Fig. 7. Temporal changes in avian densities $(m e a n \pm S D)$ at the Nararthali and Rasomati wetlands. Ducks/grebes and waders.

much higher densities than at Nararthali, although their density rapidly declined at Rasomati from 2010/2011. Prior to 2013/2014, the wetland-dependent and associated bird densities were also comparatively higher at the Rasomati wetland. The decline in overall bird density was the outcome of the steady decline in the densities of both residents and winter visitors at the Rasomati wetland (Fig. 8). In contrast, the Nararthali wetland supported a high density of resident birds, which was highest in 2013/2014. Although the density of winter visitors declined in 2010/2011 and 2011/2012 at the Nararthali wetland, their density steadily increased from 2012/2013. The density of winter visitors was much lower at Rasomati than at the Nararthali wetland throughout the study period and declined from 2010/2011. 

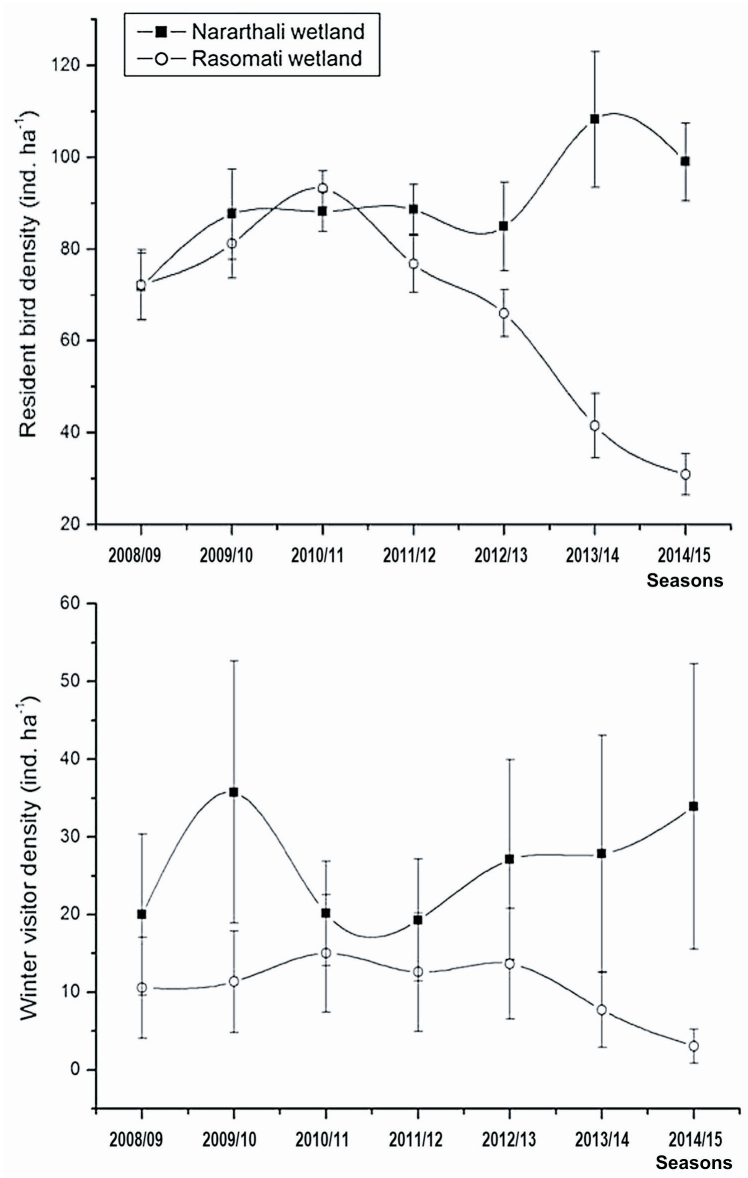

Fig. 8. Temporal changes in avian densities (mean $\pm S D)$ at the Nararthali and Rasomati wetlands. Residents and winter visitors.

\section{DISCUSSION}

It is evident from the present study that the two wetlands, located in close vicinity within the forested tract of the Himalayan foothills, were quite different in terms of avian density and community structure during the winter months of individual years. Although these wetlands were of comparable size and had similar macro-climatic and geophysical conditions, the differences in the density and diversity of wetland birds made it possible to investigate the impact of management aspects which may affect wintering migratory waterbirds. Little change was noted in rainfall and maximum/minimum air temperatures when the present dataset (2008-2015) was compared with that of the past century (1901-2000) for the eastern Himalayan forested Terai region. The present study showed that in recent years the Rasomati wetland had experienced a steady decline in avian density, while in the Nararthali wetland the 
numbers of both residents and migrants were stable over the years. The recent decline observed in the density of migratory waterbirds at the Rasomati wetland was not due to any climatic perturbation at the regional level, as we recorded a significant and steady increase in the numbers of these waterbirds at the Nararthali wetland, located in the same region. Density at Nararthali increased over the years of the study by $44.6 \%$ for all birds, $44.7 \%$ for waterbirds, $66.2 \%$ for winter visitors, and $38.6 \%$ for residents, while it decreased by $59.0 \%, 59.1 \%, 71.1 \%$ and $57.2 \%$, respectively, at Rasomati. However, the species richness in both wetlands was comparable, which indicates that the Rasomati wetland was less preferred by waterbirds and by wetlanddependent and associated birds as their wintering site. It should be noted that the Rasomati wetland, which is in close proximity to the Torsha River, experienced massive siltation due to severe flooding in the 2012 monsoon (Dey 2015), and consequently from 2012/2013 onward, resulting in huge growth of aquatic macrophytes and a drastic decline in the density of wintering bird species. This wetland gradually became weed-choked, and a large portion of the wetland turned into grassy meadow for most of the year.

In recent years, the Rasomati wetland has remained choked with water hyacinth throughout the year. Prior to 2011/2012, the floating macrophytes were manually cleared well before the wintering season. In later years, however, the clearing operation was either skipped or carried out during the period of arrival of wintering birds. Rajpar and Zakaria (2014) reported that the vegetation cover of wetlands significantly influences migratory bird density. Surely the clearing operations had a positive impact on the Rasomati wetland for wintering of waterbirds. The Rasomati wetland had suffered natural retrogressive changes that lentic water bodies usually undergo over a prolonged period. However, such retrogressive changes were accentuated due to the lack of proper management. Part of the Rasomati has recently been converted into a grazing field for the livestock of adjacent villages. The Patlakhawa-Rasomati ecotourism complex was developed by the Coochbehar Forest Division 2008/2009. The main attraction was the Rasomati beel located in the Patlakhawa forest, which was a game reserve belonging to the king of Coochbehar. This wetland used to shelter large numbers of residential and migratory birds, and the local Panchayet (selfgovernment), with the help of the West Bengal Forest Department, designated a picnic site at the entrance of PPF and allowed a paddle boating facility for tourists in the Rasomati wetland (Roy et al. 2010). Tourists were also allowed to take a $6 \mathrm{~km}$ jungle trek through PPF to reach the wetland. To observe birds and other wild animals, a $17 \mathrm{~m}$ high watchtower was constructed at the edge of the Rasomati wetland. The effort immediately became a major tourist attraction. Indiscriminate tourist activities at this site may have contributed to the decline of bird diversity and abundance at Rasomati since 2008/2009. Karmakar (2011) recorded that an average of 80 USD was earned through ecotourism at the Rasomati wetland during the non-wintering period (April through September), which increased to 1065 USD during the wintering period (October through March), This meant an increase of $1231 \%$ in revenue through ecotourism in a year. Such an enormous tourist influx during the wintering period of migratory waterbirds surely had adverse effects on avian diversity and abundance. The alarming decline in wintering bird density was noticed after 2011/2012. 
Furthermore, the habitats of the Greater One-horned Rhino (Rhinoceros unicornis) were in urgent need of reorganization in the new areas, as revealed by many cases of straying (Chakrabarti 2013). PPF was selected for development as an alternative habitat for rhinoceroses, especially in and around the Rasomati wetland and on the bank of the Torsha River, encompassing a periphery of $20 \mathrm{~km}$ and enclosing an area of $7.77 \mathrm{~km}^{2}$. Some selected vegetation, such as Saccharum narenga (dhadda) and Alpinia nigra (purundi), was cultivated at the proposed areas as food sources for rhinoceroses. However, the project was abandoned due to lack of funding. The utter neglect in the conservation of lakes of national importance became evident at a question-answer session at the Indian parliament. In answer to questions on the environment in the Parliament (2012-2013 Budget Session), it was stated that the funding made available for conserving the wetlands of West Bengal under NWCP for the National Lake Conservation Plan amounted to 4.0 crores, 0.0 crores and 1.3 crores for the financial years 2008-2009, 2009-2010 and 2010-2011 respectively.

The category of protected area status and related stringent legal measures were also significant for the effective management of wetlands of importance for wintering birds. As the Rasomati wetland was located in the PPF, protection and conservation efforts were far less intense than in BTR. Therefore, anthropogenic interferences such as tourism, fishing and cattle grazing were pronounced in the Rasomati wetland. In contrast, the Nararthali wetland was well managed and strictly protected within the territory of the Tiger Reserve and National Park. Datta (2011) studied the impact of human interference on avian diversity of the Domohani beel and the Gajoldoba beel and pointed out that wetlands facing high anthropogenic disturbances were less preferred by winter migrants, especially ducks. A proper management plan and ecorestoration strategy could sustain a healthy community of waterbirds in the wetland. The habitat heterogeneity at the Nararthali wetland supported a variety of species. The diverse macrophytes of this wetland and habitats such as reed beds, exposed mud banks with sparse vegetation or with vegetation cover, grassy meadows, and peripheral scrubs offered a variety of foraging and roosting places for waterbirds. Different waterbirds preferred different types of habitats and formed different foraging guilds (Liordos 2010, Chatterjee et al. 2020). Different types of aquatic insects and molluscs at the Nararthali wetland (Nandi et al. 2004) served as a food base for several wetland birds. Ali (1996) pointed out that the diversity of entomonekton was important for attracting different types of waterbird species. Invasive free-floating macrophytes (E. crassipes) were well managed by the forest authority and provided ample open water for waterbirds, especially for diving and dabbling ducks. Lesser Whistling-ducks (Dendrocygna javanica) were generally the most abundant resident/local migrants at the wetlands of the Gangetic plains (Mazumdar et al. 2007, Roy et al. 2011). These ducks were observed to rest on weed-covered portions of wetlands in the daytime. However, other diving and dabbling ducks preferred shallow or deep water with submerged vegetation (Ali and Ripley 1987). Therefore, both residents and winter visitors congregated at the Nararthali wetland in higher numbers to utilize its diverse resources.

The SHE analysis compared the long-term trends of both taxonomic and functional composition, which was very similar in these two wetlands. The habitat quality 
of the Nararthali and Rasomati wetlands was comparable for nearly half of the sampling period, and thus the results for SHE analysis appeared to be very similar, representing evenness of samples in terms of expected and observed species richness in both wetlands. Interestingly, larger numbers of rare species were recorded in Rasomati than in Nararthali until 2011/2012. In contrast, the lower evenness and higher dominance at Rasomati than at Nararthali possibly reflect the species-wise sparse importance values at Rasomati till 2011/2012. Spatially Constrained Rarefaction (SCR), on the other hand, is a widely used technique for comparing the species richness of samples that differ in area, volume, or sampling effort (Chiarucci et al. 2009). To compare the overall diversity of two wetlands that did not differ much in either the number of species or the number of individuals during at least a part of the sampling period, species accumulation curves were constructed on the data. Such individualbased rarefaction encouraged statistical sub-sampling without replacement from the larger of the two original datasets. Therefore, individual-based rarefaction computed the expected number of species in a sub-sample drawn at random from a single representative sample from an assemblage. However, individual-based rarefaction did not preserve the spatial structure of the data and assumed random mixing among individuals of all species. In contrast, sample-based rarefaction computed the expected number of species when samples were drawn at random, without replacement, from a set of samples that was representative of the assemblage. Gotelli and Colwell (2011) pointed out that the fundamental difference between these two rarefactions is that sample-based rarefaction by design preserved the spatial structure of the data, which might reflect special aggregation or segregation both within and between species. Both the individual-based and sample-based rarefaction curves constructed on the present data sets clearly indicate higher richness at Nararthali.

\section{CONCLUSION}

BirdLife International identified four Endemic Bird Areas (EBAs) which partially or fully overlap with the Himalaya hotspot. The Eastern Himalaya EBA overlapped with part of the Indo-Burma Hotspot and sheltered nearly 20 endemic species, including four species that were fully endemic to the Himalayas (Stattersfield et al. 1998). The Himalayan hotspot, especially sub-Himalayan ecosystems, requires greater attention due to their importance as wintering habitats for many threatened birds, including waterbird species. According to Crick (2004), Marra et al. (2005) and Sekercioglu et al. (2012), changes in avian community structure on global or regional scales are an important indicator of the effects of climate change in tropical ecosystems. However, local diversity parameters, especially for migratory waterbirds, are crucially dependent on habitat quality. Waterbird habitats are being lost on a global scale through human activity. In the present work, anthropogenic interactions, besides variables such as the morphology, topography, and vegetation of the wetlands, were considered in order to assess the impact of habitat configuration on waterbird richness and abundance. It was apparent that only sincere efforts at habitat management and restoration could save the wetland habitats from degradation and encour- 
age sustained use by waterbirds as wintering sites. The present work has shown that effective management initiatives, rather than climatic changes, have played an important role in stabilizing the wintering populations of waterbird species and other winter migrants at the wetlands and associated forested tracts of the foothills of the Eastern Himalayas.

\section{ACKNOWLEDGEMENTS}

The authors thankfully acknowledge the support, infrastructure and encouragement provided by the PCCF (HoFF), PCCF Wildlife, West Bengal; the Field Director and Deputy Field Directors of BTR (East and West); and the Divisional Forest Officer of Coochbehar Forest Division, West Bengal. We are also thankful to the forest staff who cooperated in many ways to complete the fieldwork. We also wish to thank the University Grants Commission, Govt. of India and DHESTBT, Govt. of West Bengal for the fellowship and contingency grant that helped in completing this work.

\section{REFERENCES}

Aarif K.M., Nefla A., Muzaffar S.B., Musammilu K.K. and Prasadan P.K. 2017. Traditional fishing activities enhance the abundance of selected waterbird species in a wetland in India. Avian Research 8: 16. doi: 10.1186/s40657-017-0073-6.

Acharya B.K., Sanders N.J., Vijayan L. and Chettri B. 2011. Elevational gradients in bird diversity in the Eastern Himalaya: An evaluation of distribution patterns and their underlying mechanisms. PLoS ONE: 6(12): e29097. doi: 10.1371/journal.pone.0029097.

Ali S. 1996. The Book of Indian birds. Bombay Natural History Society, Mumbai.

Ali S. and Ripley S.D. 1987. Compact Handbook of Birds of India and Pakistan. Oxford University Press, Delhi.

Bibby C.J., Burgess N.D. and Hill D.A. 1992. Bird Census Techniques. Academic Press, London.

BirdLife International. 2008. Waterbirds are showing widespread declines, particularly in Asia. http://www.birdlife.org/datazone/sowb/casestudy/71.

BirdLife International. 2016. Important Bird and Biodiversity Area factsheet: Buxa Tiger Reserve (National Park). http://www.birdlife.org.

Both C., Bouwhuis S., Lessells C.M. and Visser M.E. 2006. Climate change and population declines in a long-distance migratory bird. Nature 441: 81-83.

Both C., van Turnhout C.A.M., Bijlsma R.G., Siepel H., van Strien A.J. and Foppen R.P.B. 2009. Avian population consequences of climate change are most severe for long-distance migrants in seasonal habitats. Proceedings of the Royal Society B. doi: 10.1098/rspb.2009.1525

Chakrabarti S. 2013. Wake up call. Sanctuary Asia December 33(6): 64-67.

Chatterjee A., Adhikari S., Barik A. and Mukhopadhyay S.K. 2013. The mid-winter assemblage and diversity of bird populations at Patlakhawa Protected Forest, Coochbehar, West Bengal, India. Ring 35: 31-53.

Chatterjee A., Adhikari S., Pal S. and Mukhopadhyay S.K. 2020. Foraging guild structure and niche characteristics of waterbirds wintering in selected sub-Himalayan wetlands of India. Ecological Indicator, 108. doi: 10.1016/j.ecolind.2019.105693.

Chatterjee A., Adhikari S. and Mukhopadhyay S.K. 2017. Effects of waterbird colonization on limnochemical features of a natural wetland on Buxa Tiger Reserve, India, during wintering period. Wetlands 37(1): 177-190. 
Chiarucci A., Bacaro G., Rocchini D. and Scheiner S.M. 2009. Spatially constrained rarefaction: Incorporating the autocorrelated structure of biological communities into sample-based rarefaction. Community Ecology 10(2): 209-214.

Conservation and Survey Division, MoEF, GoI. 2009. National Wetland Conservation Programme Guidelines for Conservation and Management of Wetlands in India. p 17.

Crick H.Q.P. 2004. The impact of climate change on birds. Ibis 146 (Suppl.1): 48-56.

Das B.K. 2012. Losing biodiversity, impoverishing forest villagers: Analysing forest policies in the context of flood disaster in a National Park of Sub Himalayan Bengal, India. Occasional paper 35, Institute of Development Studies, Kolkata, p 29.

Datta T. 2011. Human interference and avifaunal diversity of two wetlands of Jalpaiguri, West Bengal, India. Journal of Threatened Taxa 3(12): 2253-2262.

Datta T. 2014. Time-activity budgets of wintering Ferruginous Duck, Aythya nyroca, at Gajoldoba wetland, Jalpaiguri, India. Turkish Journal of Zoology 38: 538-543.

Dey S. 2015. Floods in Cooch Behar: Nature, analysis and mitigation. International Journal of English Language, Literature and Humanities 3(5): 294-312.

Gibbons D.W. and Gregory R.D. 2006. Birds. In Sutherland WJ (eds) Ecological Census Techniques: A Handbook. Cambridge University Press, p 27-28.

Gopal B. 1995. WWF Handbook of Wetland Management. World Wildlife Fund publication, New Delhi, p. 1-395.

Gopi Sundar K.S. and Kittur S. 2013. Can wetlands maintained for human use also help conserve biodiversity? Landscape-scale patterns of bird use of wetlands in an agricultural landscape in north India. Biological Conservation 168: 49-56.

Gotelli N.J. and Colwell R.K. 2011. Estimating species richness. In Magurran A, McGill B (eds) Biological diversity: frontiers in measurement and assessment. Oxford University Press, p. 39-54.

Grimmett R., Inskipp C., Inskipp T. 2011. Birds of the Indian Subcontinent. Oxford University Press.

Haq U.R., Eiam-Ampai K., Ngoprasert D., Sasaki N. and Shrestha P.R. 2018. Changing landscapes and declining populations of resident waterbirds: A 12-years study in Bung Boraphet Wetland, Thailand. Tropical Conservation Science 11: 1-17.

Islam M.Z. and Rahmani A.R. 2004. Important Bird Areas in India: Priority sites for conservation. Indian Bird Conservation Network. Bombay Natural History Society and BirdLife International (UK).

IUCN. 2016. The IUCN Red List of Threatened Species ${ }^{T M}$ (version 2016-3). http://www.iucnredlist.org

Jonzén N., Lindén A., Ergon T., Knudsen E., Vik J.O., Rubolini D., Piacentini D., Brinch C., Spina F., Karlsson L., Stervander M., Andersson A., Waldenström J., Lehikoinen A., Edvardsen E., Solvang R. and Stenseth N.C. 2006. Rapid advance of spring arrival dates in long-distance migratory birds. Science 312(5782): 1959-1961.

Joshi K. and Bhatt D. 2011. Birds of three different forest habitats in Nainital district (Western Himalaya), Uttarakhand, India. Indian Birds 7(2): 33-37.

Karmakar M. 2011. Ecotourism and its impact on the regional economy - A study of North Bengal (India). Tourismos 6(1): 251-270.

Liordos V. 2010. Foraging guilds of waterbirds wintering in a Mediterranean coastal wetland. Zoological Studies 49(3): 311-323.

Liordos V., Pergantis F., Pergantiand I. and Roussopoulos Y. 2014. Long-term population trends reveal increasing importance of a Mediterranean wetland complex (Messolonghi lagoons, Greece) for wintering waterbirds. Zoological Studies 53(12). doi: 10.1186/1810-522X-53-12.

Ma Z., Cai Y., Li B. and Chen J. 2010. Managing wetland habitats for waterbirds: An International perspective. Wetlands 30(1): 15-27.

Marra P.P., Francis C.M., Mulvihill R.S. and Moore F.R. 2005. The influence of climate on the timing and rate of spring bird migration. Oecologia 142: 307-315. 
Mazumdar S., Mookherjee K. and Saha G.K. 2007. Migratory waterbirds of wetlands of southern West Bengal, India. Indian Birds 3(2): 42-45.

Miller-Rushing A.J., Lloyd-Evans T.L., Primack R.B. and Satzinger P. 2008. Bird migration times, climate change, and changing population sizes. Global Change Biology. doi: 10.1111/j.13652486.2008.01619.x.

Mohan D. and Kumar R. 2010. Breeding birds of Kothri valley, eastern Garhwal Himalayan foothills, India. Forktail 26: 75-81.

Morabito G. 2016. Phytoplankton assemblages in Lake Orta: Has functional structure recovered in one of the largest acidic lakes in the World?. Journal of Limnology 75(s2): 142-152.

Mundava J., Caron A., Gaidet N., Couto F.M., Couto J.T., Garine-Wichatitsky M.D. and Mundy P.J. 2012. Factors influencing long-term and seasonal waterbird abundance and composition at two adjacent lakes in Zimbabwe. Ostrich 83:69-77.

Naithani A. and Bhatt D. 2012. Bird community structure in natural and urbanized habitats along an altitudinal gradient in Pauri district (Garhwal Himalaya) of Uttarakhand state, India. Biologia 67(4): 800-808.

Nandi N.C., Mukhopadhyay P., Ghosh S.K and, Das S.K. 2004. Notes on aquatic entomofauna of Narathaly Lake of Buxa Tiger Reserve, West Bengal. Records of the Zoological Survey of India 102(1 and 2): 53-56.

O'Connell T.J., Jackson L.E. and Brooks R.P. 2000. Bird guilds as indicators of ecological condition in the central Appalachians. Ecological Applications 10(6): 1706-1721.

Pandit M.K., Sodhi N.S., Koh L.P., Bhaskar A., Barry W. and Brook B.W. 2007. Unreported yet massive deforestation driving loss of endemic biodiversity in Indian Himalaya. Biodiversity and Conservation 16: 153-163.

Paracuellos M. and Tellería J.L. 2004. Factors affecting the distribution of a waterbird community: The role of habitat configuration and bird abundance. Waterbirds 27(4): 446-453.

Paton D.C., Rogers D.J., Hill B.M., Bailey C.P. and Ziembicki M. 2009. Temporal changes to spatially stratified waterbird communities of the Coorong, South Australia: implications for the management of heterogenous wetlands. Animal Conservation 12: 408-417.

Rajpar M.N. and Zakaria M. 2014. Effects of habitat characteristics on waterbird distribution and richness in wetland ecosystems of Malaysia. Journal of Wildlife and Parks 28: 105-120.

Roy P.B., Roy T.B. and Saha S. 2010. Pro-poor tourism as an approach towards community development: A case study. South Asian Journal of Tourism and Heritage 3(2): 90-98.

Roy U.S., Goswami A.R., Aich A. and Mukhopadhyay S.K. 2011. Changes in densities of waterbird species in Santragachi Lake, India: Potential changes in limnochemical variables. Zoological Studies 50(1): 76-84.

Rudra K. 2012. Atlas of Changing River Courses in West Bengal 1767-2010. Sea Explorers' Institute, Kolkata.

Sekercioglu C.H., Primack R.B. and Wormworth J. 2012. The effects of climate change on tropical birds. Biological Conservation 148: 1-18.

Stattersfield A.J., Crosby M.J., Long A.J. and Wege D.C. 1998. Endemic bird areas of the world: Priorities for biodiversity conservation. BirdLife Conservation Series 7. BirdLife International Cambridge.

Visser M.E., Perdeck A.C., van Balen J.H. and Both C. 2009. Climate change leads to decreasing bird migration distances. Global Change Biology. doi: 10.1111/j.1365-2486.2009.01865.x.

Wang Y., Fraser J.D. and Chen J. 2017. Wintering waterbirds in the middle and lower Yangtze River floodplain: Changes in abundance in distribution. Bird Conservation International 27(2): 167-186.

Ward M.P., Semel B. and Herkert J.R. 2010. Identifying the ecological causes of long-term declines of wetland-dependent birds in an urbanizing landscape. Biodiversity and Conservation 19: 3287-3300. 